\title{
Relationship between Teacher Motivation and Transformational Leadership Characteristics of School Principals
}

\author{
Dr. Figen Eres \\ Faculty of Education, Gazi University \\ Ankara, Turkey \\ Tel: 90-312-484-4631 E-mail: feres@gazi.edu.tr
}

Received: July 22, 2011 Accepted: August 27, $2011 \quad$ DOI: 10.5296/ije.v3i2.798

\begin{abstract}
The aim of the study was to determine the motivation levels of teachers working in primary school and the level of transformational leadership qualities of school principals based on the perceptions of teachers; and then the investigate of the relationship between teacher motivation and the transformational leadership qualities of school principals. The sample consists of 397 class teachers and subject matter teachers who were chosen randomly and work at the central boroughs of Ankara. As a result of the study, it was determined the motivation levels of teachers is "partly satisfied" whereas the transformational leadership characteristics level of school principals is "rarely."At the end of the study, no meaningful relationship was found between the transformational leadership characteristics of school principals and the level of teacher motivation.
\end{abstract}

Keywords: Transformational leadership, School principals, Teacher motivation, Primary school, Turkey 


\section{Introduction}

Reform methods of schools can't adapt to social and cultural changes fast enough. Traditional methods result in the failure of schools (Jacob, 2007). On the other hand, modern school management considers the school organisation as the focus of transformation. The presence of a leader has been necessary as the provider of this transformation and this leader has been expected to take on the role of tranformational leader in schools (Bottery, 2001). It is these transformational leaders who will market the transformation of the organisation and affect and direct its followers in this way (Palmer, Walls, Burgress and Stough, 2001; Tichy and Ulrich, 2008). This is so because the role of transformational leadership behaviour is quite important in keeping up with scientific knowledge and technology at school, the adaptation of the school to changing environmental conditions and increasing the quality of education (Leithwood, 1992). The school principal as a transformational leader is expected to make the school compatible with society and science by providing innovation with this role. It is because schools that need to change and restructure themselves in order to continue their existence in a constantly changing and dynamic framework are in need of leaders who can lead the way for such changes.

Transformational leadership is the restructuring of the system in order for the mission and vision of people to be redefined and their responsibilities refreshed so that the goals could be reached (Leithwood, 1992). Therefore transformational leadership aims to ensure that the staff identifies themselves with the goals of the organization (Podsakoff, Mckanzie, Moorman and Fetter, 1990). Another characteristic of transformational leadership is that it is effective on the followers. Due to this effect, the followers trust the leader and as a result, the followers of a transformational leader show a tendency to do more than what is required of them (Yukl, 1999). According to Burns (1978) transformational leadership is a process in which leaders and their followers bring each other to a higher level of ethic and motivation. In other words, it is the activation of the present energy in the followers by the leader through positive active interaction with the followers and using this energy for organisational aims (Krishan, 2001). The most important point in the definition are the goals, these goals are independent from each other but are also related.

For this reason, it is necessary to firstly determine the mission, vision and strategies of the organisation and its responsibilities (Leithwood, Menzies, Jantz and Leithwood, 1996). Transformational leaders as a transformational intermediary are those who can create and put into practice clear visions for the organisation, strenghthen its followers for higher standards, behave in order to have others' trust in themselves, and add meaning to organisational life (Northhouse, 1997). Transformational leaders activate others to become postmodernist and strenghten the school culture with real changes (Jacobs, 2007). Transformational leaders aim to have their employees identify themselves with the aims of the organisation (Podsakoff, Mckanzie, Moorman and Fetter, 1990).

In this respect, in the school which is based on three leadership functions as mission and performance-based and culture-oriented, transformational leadership, intellectual knowledge, ideal effect and personal motivation are the basic elements (Bass and Avolio, 1993). In this 
position, transformational leadership embraces a postmodern way of thinking and helps others in sharing their visions. It has been proved through research that in an organisation with transformational leaders, there is higher productivity and that the workers are happier and there are fewer negative incidents (Robbins, 1996). Leaders increase their workers' motivation through such behaviour (Bass,1990; Greenberg and Baron, 2000; Luthans, 1992). As the human relations and communicative skills of a transformational leader are developed (Sosik, Godshalk and Yammarino, 2004). They are effective in persuading and directing their followers (Glad and Blanton, 1997). While doing this, the leader has a profile which takes into consideration the expectations of its followers (Conger, 1999).

Though transformational leaders have many positive characteristics, they are also criticized by certain authors. One of these criticisms is the ability of transformational leaders to abuse this power (Hall, Johnson, Wysocki and Kepner, 2002) and even to show narcissistic tendencies. In addition, the character traits of the followers can react negatively towards transformational leadership (Stone, Russell and Patterson, 2003). It can be stated that the existence of transformational leadership depends on the characteristics of the organizational management and the staff. Another point which needs to be criticized is that, the theory of transformational leadership is not effective when the staff do not possess the necessary skills and information. It will be very difficult to motivate such a staff member as a transformational leader. Another issue related to transformational leadership is the effect of social culture on transformational leadership.

Leadership is not shaped independent of social culture. It has been found through studies that transformational leadership is weaker in eastern cultures (Leong and Fischer, 2010). The relationship between individuals with a traditional culture and transformational leadership is very little (Spreitzer, Perttula and Xin, 2005). In addition, when looking at transformational leadership from a theoretical point of view; it can be stated that it expresses the "what" but is insufficient in explaining the "how". To sum up, conceptual weakneses of transformatinal leadership reduce its capasity although theory of transformational leadership provides important insights about the nature of effective leadership (Yukl, 1999).

Motivation is the internal and external stimulants that determines the behaviour and the priority of a person (Munn, 1968). It is the basic meaning for the cause and explanation of a behaviour. The effects that provide motivation are related to needs which have not been met (Covey, 2004). Motivation is the force that causes an individual to act in a certain manner or to be oriented towards it (Gibson, Ivancevich and Donnelly, 1988). The needs and requests which make up the foundation of the concept of motivation are mainly shaped by the culture, social justice and structure in which the individual is in, as well as the emotional and spiritual make up of the person. The motivation of human beings is closely related to all the objects that the person establishes relations with (Bingol, 2006). In addition, personal traits, physical conditions, previous experiences and environmental conditions are related to motivation. When viewed from a managerial view, motivation is deciding on what method to choose to activate an individual (Ruthankoon and Ogunlana, 2003). If a task needs to remain motivational, the person performing the task as well as his or her superior needs to be on the same page in regards to their expectations from the task. Together with this, it is a known fact 
that the experience and skills of the staff are important factors in increasing motivation (Pandey, Wright, and Moynihan 2008). However, if the staff fails to find a connection to the outcome of the task they perform for the goals of the organization, this can negatively affect their motivation. In other words, the goals of the organization may not always be motivational (Scott and Pandey, 2005).

Motivated workers are more dedicated to the organisation. They have job satisfaction and as a result of this, they work more productively (Osterloh, Bruno and Frost, 2001). For this reason, managers motivate their employees to use their knowledge and skills towards organisational aims (Lindner, 1998). School principals have to keep in mind that teacher who do not have job satisfaction and are demotivated may weaken educational programmes (Snowden and Gorton, 2002). For this reason, they have to use different approaches to motivate teachers (Lunenburg and Ornstein, 2004). There are a variety of factors in motivating the staff. These can be summarized as a secure future, good and healthy working conditions and positive communication with peers as well as managers (Öztürk and Dündar, 2003). The most important factor for the motivation of teachers is the school administration. The participation of teachers in decision making, the sharing of authority and responsibility, compensation and rewards can motivate them (Kocabaş and Karaköse, 2005). Another factor is the communication and interaction the teachers have with their colleagues and students (Güçlü, 1996). In addition, the physical conditions of the school, as well as the issuing of the tools that will be used during the teaching also motivate the teachers (Atakl1, 1996). Another factor is the relationship of the teacher with the families and their surroundings (Barl, Bilgili, Çelik and Bayrakçeken, 2005; $\mathrm{Wu}, 2003)$. The communication that the teachers establish with the families positively impacts the success of the student and results in the teacher having a sense of peace. School principals must be also sensitive towards the social needs of teachers. A principal who is not aware of this and does not display effort to fulfill this, will have difficulty in motivating people (Bursalıoğlu, 2002). For this reason, principals have to understand what motivates teachers and be aware of how they can enhance energy and motivation in reaching the aims of schools (Adair, 2002). This is closely related to the quality and adequacy of school principals. A principal who has the necessary proficiency may motivate his/her teacher with a visionary view.

Bass (1990) described that motivation is a sub-dimension of transformational leadership. Motivation has been shown to be an inspiring component of transformational leadership (Simola, Barling ve Turner, 2010; Sosik, Godshalk, and Yammarino, 2004). Researchs have shown a positive relationship between transformational leadership and motivation. Transformational leadership increases motivation of employees (Park and Rainey 2008). But Caldwell ve Spink (1992) determined that sub-dimensions of transformational leadership were cultural, educative, strategical and responsive. Also Leithwood and his colleagues have defined transformational leadership based on schools. Researches have explained the functions of transformational leadership in three fields as (Leithwood and Jantzi, 1990; Leithwood, Jantzi and Fernandez, 1994; Leithwood, 1995): Those which are mission- based develop in a great sense the vision shared in the school. Performance-based ones expect high performance, provides individual support and supports intellectual knowledge. Those which 
are culture- oriented determine organisational values, enhance productive school culture and increase the share of the decision mechanism. However, although there is limited research on leadership style and teacher motivation, recently there has been research arguing that transformational leadership is not sufficient for schools (Marks and Printy, 2003). Then It's possible to say that transformational leadership has different characteristics in school.

The success of the leader varies depending on their personal make up, the size of the business they work in as well as their country and culture (Tosi, Mero and Rizzo, 2000). In Turkey, the school principals work in connection to the Ministry of Education. The education policies of the schools as well as the decisions regarding the school management are made by the Ministry of Education. These decisions are passed into law through legal arrangements. The school principals are than ordered to implement them. In summary, the school principals do not decide on educational policies regarding their schools and cannot make basic decisions regarding education and training. In addition to this, the lack of resources as well as the operational and structural problems that are brought forward by the hierarchical structuring, are all obstacles in the path of effective education being implemented (Özdemir, 1998). It seems rather difficult for management in a system with such characteristics to play the role of a transformational leader. This is because transformational leaders aim to create subordinates which are independent, able to think critically and as a result be able to make important contributions. They are able to undertake risks, not be afraid of making mistakes and are aware that mistakes are an opportunity for improving themselves (Selen, 2001). However it seems impossible for a strictly centralized structure to not prevent the freedom that lies at the foundation of leadership.

Educational organisations are those which have been set up to realise a specific social aim which shape the future of a society. The quality of education determines the future of a society. Schools, which have the responsibility of fulfilling muti-dimensional functions, are affected by internal and external environmental factors. Some of these factors may be negative. The elimination of negative factors depends on the presence of leader school principals. It is understood that in the studies carried out in Turkey concerning school leadership, mainly the transformational leadership qualities of school principals are determined. Studies on the comparison of transformational leadership with other disciplines are limited. There is no research on the transformational qualities of school principals and teacher motivation, and the relationship between the two in Turkey. In this respect, I wish to contribute to field study by determing the motivation levels of teachers, the transformational leadership qualities of school principals and the relationship between these qualities and teacher motivation. In this context, the aim of the study is to determine the motivation levels of teachers working in primary school and the level of transformational leadership qualities of school principals based on the perceptions of teachers and the investigate of the relationship between teacher motivation and the transformational leadership qualities of school principals.

\section{Method}

\subsection{Population and sampling}




\section{Ml Macrothink}

The study was carried out in the 2009-2010 academic year. The population of the study is composed of primary education teachers employed in the primary schools in Ankara a province located in the central Anatolia in Turkey. A sample size was identified by using the theoretical sample size table developed by Yamane (2001). To prevent the negative effect of a possible low return rate, the working sample size was identified as 450 . There were 397 returned questionnaires from the distribution of 450 surveys. The sample of the study is composed of a total of randomly selected teachers in the research.

\subsection{Data Gathering Instrument and Data Analysis}

In the study, two scales were used to determine the motivation levels of teachers working in primary schools and to determine their perception levels of transformational ledership qualities of school principals.

The review of the literature was followed by unstructured interviews with 70 teachers about the factors of teachers' motivation. These activities led to a draft of the Teachers' Motivation Scale, which was analyzed by a panel of experts that included two professors of education and educational research. The panel of experts verified the accuracy and importance of each survey item. I studied the factor analysis suitability of data by using Kaiser -Meyer- Olkin (KMO) and Barlett Sphericity test and the KMO 0.66 and Barlett Sphericity test was found to be meaningful. The total explained variance in this scale with a structure of five factors is $\% 75$. This ratio was seen to be sufficient in evaluating analysis. It was assumed that the items in the scales were suitable for assessing the motivation level of teachers. In addition, for each sub-dimension, Cronboach Alpha reliability coefficient has been calculated. The reliability coefficient of the scales subdimensions range between .59-.83. It is accepted that the values obtained are sufficient in measuring the motivation levels of teachers. A 5-point Likert-type scale was used to measure teacher motivation with options ranging from 5 ('very satisfactory') to 1 ('very unsatisfactory').

Table 1. Factor loadings of teacher motivation and reliability

\begin{tabular}{|l|c|c|c|}
\hline Subdimensions & Number of items & Factor loadings & Cronbach's Alpha \\
\hline Parent & 4 & $.46-.87$ & .83 \\
\hline $\begin{array}{l}\text { Physical conditions of the } \\
\text { school }\end{array}$ & 5 & $.45-.76$ & .69 \\
\hline School management & 4 & $.47-.80$ & .69 \\
\hline Students & 4 & $.50-.84$ & .59 \\
\hline Colleague relationships & 2 & $.68-.82$ & .64 \\
\hline
\end{tabular}

In the study, 'TheTransformational Leadership Scale' which was developed by Brestrich (1999) and which is used in educational organisations in Turkey, has been used. As shown in Table 2, the reliability coefficients related to the sub-dimensions within Transformational Leadership scale are significantly high. 
Table 2. Reliability of transformational leadership

\begin{tabular}{|l|c|c|}
\hline Subdimensions & Number of items & Cronbach's Alpha \\
\hline Providing vision and inspiration & 5 & .93 \\
\hline Forming role models & 3 & .91 \\
\hline Dedicating yourself to aims of the group & 4 & .94 \\
\hline Providing individual support & 4 & .89 \\
\hline Arousing intellectual wish & 3 & .93 \\
\hline $\begin{array}{l}\text { Keeping high performance expectation on } \\
\text { the agenda }\end{array}$ & 2 & .94 \\
\hline
\end{tabular}

It has been found that no item decreases the reliability of the leadership scale and has to be eliminated from the analysis. A 5-point Likert-type scale was used to measure teacher motivation with options ranging from 5 (Always) to 1 (Never).

As a result of the Kolmogorov- Smirnov $\mathrm{Z}$ test, it has been found that the data set has not been distributed as normal. Due to this, in the data obtained in the study, arithmetic mean, standard deviation, Mann- Whitney U test and Kruskall Walls test were used. Also The Spearman's rho test was used in finding the relationship between teacher motivation and the transformational leadership perception of school principals.

\subsection{The Individual Characteristics of the Participants}

$38.1 \%$ of the participants are women and $61.9 \%$ are men. $61 \%$ of the participants have a seniority of $1-10,31.2 \% 11-20$ years and, $7.8 \%, 21$ years and over. $41.1 \%$ of the participants are class teachers, $58.9 \%$ are subject matter teachers. $88.9 \%$ have graduate degrees whereas $11.1 \%$ have post-graduate degrees.

\section{Findings}

In this part, the motivation levels of class and subject matter teachers depending on various variables, the transformational leadership characteristics of school principals according to teacher perceptions and the relationship between these findings have been evaluated and commented on.

Table 3. The motivation levels of teachers

\begin{tabular}{|l|c|c|c|}
\hline Subdimensions & $n$ & $M$ & $S D$ \\
\hline Parent & & 2.73 & .84 \\
Student & & 2.64 & .98 \\
Colleague relations & 397 & 2.26 & .90 \\
School management & & 2.83 & .92 \\
The physical qualities of the school & & 2.61 & .95 \\
Total points for motivation level & & 2.65 & .46 \\
\hline
\end{tabular}

The motivation levels of teachers is as "partially satisfied". When the means of the subdimensions are studied, the subdimension of colleague relations is "not satisfied $(M=2.26)$ 
whereas the other subdimensions are "partially satisfied" $(M=2.61-2.83)$. In a working environment where there is dissatisfaction in colleague relations, it can be said that there is a communication problem among the teachers. It can be seen in the table that the subdimension 'school managament' has the highest mean. Based on the table, it can be said that the motivation levels of teachers is low and that teachers are less affected by factors other than the principals. However, it is not possible to say that school principals have a positive effect on teacher motivation. When the views of the participants are evaluated based on gender, there isn't a meaningful difference between female and male teachers in terms of motivation level means $(U=16566.500)$. There isn't a meaningful difference in terms of motivation level means between class teachers and subject matter teachers $(U=18538.000)$. Although there is no difference in the means of variables, the motivation levels of female teachers and subject matter teachers are more positive. As a result of the Kruskal Wallis analysis, no meaningful difference has been found in terms of motivation level means among teachers of different seniorities, $\chi^{2}(n=397)=3.75$. However, there is a meaningful difference in terms of motivation level means among teachers with different educational degrees. There is no meaningful difference concerning motivation levels between teachers with undergraduate and graduate degrees $(U=4535.000)$ and teachers with undergraduate and post-graduate degrees $(U=257.500)$. However, there is a meaningful difference between teachers with graduate and post- graduate degrees concerning motivation levels $(U=2067.000)$. The motivation levels of teachers with graduate degrees are more positive. Based on this result, it may be thought that teachers with post-graduate degrees have different expectations compared to the others.

Table 4. The means of transformational leadership qualities of school principals based on the perceptions of teachers.

\begin{tabular}{|l|c|c|c|}
\hline Subdimensions & $n$ & $M$ & $S D$ \\
\hline Providing vision and inspiration & & 2,25 & .94 \\
Forming role models & & 2,34 & 1.05 \\
Dedicating yourself to group goals & 397 & 2,36 & 1.04 \\
Providing individual support & & 2,36 & 1.01 \\
Arousing intellectual wish & & 2,52 & 1.09 \\
Keeping high performance expectations on the & & 1,90 & 1.13 \\
agenda & & & \\
Total points for transformational leadership. & & 2,31 & .95 \\
\hline
\end{tabular}

When the points the participants gave to the items on their perceptions of the transformational leadership qualities of school principals are studied, the general means of the transformational leadership qualities of school principals has the general means "rarely" $(M=2.31)$. As can be seen in the table, the highest mean is for the subdimension "Arousing Intellectual Interest" $(M=2.52)$. The lowest mean is the subdimension "Keeping high performance expactations on the agenda" $(M=1.90)$ Based on these results, the transformational leadership qualities of school principals within the context of the sample are below average. In other words, school principals rarely display transformational leadership qualities based on the perceptions of teachers. According to the views of teachers, there is no 
difference in the transformational leadership qualities of school principals in terms of gender $(U=18392.000)$ and between class teachers and subject matter teachers $(U=17381.500)$. While the means of female and male teachers do not change based on the table, subject matter teachers think more positive of school heads despite the fact that no difference exists. When comparisons are made based on seniority and educational levels no difference has been found in terms of transformational leadership qualities between teachers with different seniorities $\chi^{2}(\mathrm{n}=397)=594$ and teachers with different degrees $\chi^{2}(\mathrm{n}=397)=302$ as a result of the Kruskal Wallis analysis. Based on these results, although the seniorities and educational levels of teachers change, their views on the transformational leadership qualities of school heads are similar. However, the views of teachers with a seniority of 21 years and over and those with graduate degrees are more positive.

Table 5. The relationship between transformational leadership qualities of school principals and teacher motivation.

\begin{tabular}{|l|c|c|c|}
\hline & Spearman's rho & $\begin{array}{l}\text { Total points for } \\
\text { transformational } \\
\text { leadership }\end{array}$ & $\begin{array}{l}\text { Total points } \\
\text { for motivation } \\
\text { level }\end{array}$ \\
\hline Total points for & $r$ & 1.000 & .011 \\
transformational & $p$ &. & .822 \\
leadership & $n$ & 397 & 397 \\
Total points for & $r$ & .011 & 1.000 \\
motivation level & $p$ & .822 &. \\
& $n$ & 397 & 397 \\
\hline
\end{tabular}

The Spearman's rho test was used to determine the relationship between teacher motivation and the transformational leadership qualities of teachers. As a result of the correlation analysis, the correlation coefficient was calculated as $r=.011$. Based on this result, the conclusion was made that there is no meaningful relationship between the transformational leadership behaviour of school principals and teacher motivation based on the perceptions of teachers.

\section{Results and Discussions}

The aim of this study was to determine the motivation levels of teachers working at primary schools and the transformational leadership qualities of school principlas according to the perceptions of teachers and to investigate the relationship between teacher motivation and the transformational leadership qualities of school principals. Based on the results of the study, the motivation levels of teachers working at primary school has been determined as "partially satisfied". There isn't a meaningful difference among teachers of different variables (Ünal, 2000). When the external motivations of teachers in this study are considered, it maybe said that teachers are dissatisfied with the abstract and concrete conditions of the school within the context of the data obtained. It is known that teachers who have high external motivation direct themselves to aim-centred activities (Ryan and Deci, 2006). The teachers who have participated in the study find external motivation sources such as managerial behaviour, the social support they get from parents and reward and punishment inadequate (Wu, 2003). In 
schools with strong school culture (Cheng, 1993) and climate (Coutts,1997), it has been found through studies that motivation levels are high. Workers have motivation despite difficult conditions, but the fact that the problems they face are not solved affect their motivation negatively (Nicholson, 2003). Based on the results of this study, it may be said that teachers are dissatisfied with conditions at school and that communication at school, school culture and climate and its conditions are factors of this dissatisfaction.

The level of transformational leadership qualities of school principals based on the views of teachers has been found as "rarely" in the study. There isn't a meaningful difference among teachers of different variables (Çelik and Eryılmaz, 2006; Taş, Çelik and Tomul, 2007). The data obtained implies that school principals are insufficient in displaying transformational leadership and school culture. Studies which have been carried out so far show that school principals who are transformational leaders direct their schools to succes by forming a shared culture _between teachers and students (Sagor, 1992). This means that the mission and vision of the school is determined by the school principal (Leithwood, 1992). It is also known that principals who possess transformational leadership qualities motivate teachers to participate in decisions (Wegge, 2000). However, based on the results of the study, it is understood that teachers can not see such behaviour in school principals. Despite this, Akbaba-Altun (2001) has reached the conclusion that school principals think that they possess transformational leadership qualities in the study he/she carried out. Based on these results, it is possible to say that school heads are aware of their transformational leadership qualities but are unable to transform this awareness to behaviour. This condition brings into mind the importance of the sufficiency of personal characteristics and communication skills of school principals (Barth, 1986; Dwyer, 1986).

The educational process, out of schools, the leadership behaviour of a school principal and this experience and values are also affected by social culture. Turkey has a dominant culture which is affected by western culture but has qualities specific to itself. The leadership behaviour of managers in Turkey is basically affected by the cultural structure of the society (Karkin, 2004) and the Turkish Education System also has a centralized, bureaucratized structure. Transformatioanl leadership is very important in countries where change is necessary (Kanungo and Mendonca, 1996). There is a tendency for innovation especally in people who are creative, curious and in favour of freedom. Transformational leadership seems attractive for such people (Triandis,1995). When viewed in this context, if teachers do not need a change and if they are not open to innovation, the transformational leadership behaviour of a school principal will not have an effect.

Another point to be considered is one concerning the leadership perceptions of teachers. The fact that the person in the managerial position has the right personal traits or the formation of suitable conditions does not necessarily mean that the teachers will accept its manager as a leader (Konrad, 2000). Leadership is also a process which is perceived differently by teachers (Lord, Brown and Freiberg, 1999) and how the leadership is accepted by teachers is related to the implicit leadership perception of teachers (Kenney, Blascovich and Shaver, 1994; Engle and Lord, 1997). The presence of a harmony between implicit leadership perception and the leader and that it provides the trust and motivation between subordinate and superior 
relationship has been proven through scientific research (Epitropaki and Martin, 2004). In this context, it may be said that the implicit leadership perceptions of teachers are not compatible with the leadership behaviour of school principals.

As a result of the study, no significant relationship has been found between the transformational leadership behaviour of school principals and teacher motivation according to the perceptions of teachers. This result is not consistent with some studies on relation between motivation and transformational leadership carried out in different countries (Eyal and Roth, 2011; George and Sabhapaty, 2010). But Ergin and Kozan (2004) explored that transformational processes don't enable to satisfy high level needs of employees in Turkey. It is thought that the centralized structure of Turkish Education System have a negative impact on the school principals' leadership qualities and motivation of teachers (Leithwood, Steinbach and Jantzi, 2002). Because centralized and bureaucratized education systems also restrict the leadership behaviour of school principals (Hallinger and Leithwood, 1998). Also transformational leadership takes into consideration just the reformist role of school principals and especially emphasises the shaping of organisation culture (Conley and Goldman, 1994; Leithwood, 1995). Although the individual characteristics of the leader in this form has an important role in the efficiency of the group, its effect on teacher motivation is not sufficient. Although transformational leadership plays an important role in the realisation of organisatioanl goals and the increasing of its aims, it lacks in motivating teachers. There was no conclusive proof that an administrator's leadership style has a direct relationship to teacher motivation (Gallmeier,1992). For this reason, the presence of a instructional leadership is necessary in schools in addition to transformational leadership (Marks and Printy, 2003). It is thought that the integration of these two types of leadership will be effective in school success and the enhancement of teacher motivation. Besides, if teachers don't have faith in school objectives, this may lead to low motivation. We must not forget transformational leadership is based upon organizational objectives. Therefore teachers with low motivation may not affected by behaviours of school principals regarding transformational leadership.

Some of the limitations of this study is that the data obtained cannot be generalized since it has been carried out at state primary schools in Ankara. However, the data obtained may set an example for future studies. In addition, more different and related research is needed on teacher motivation and the transformational leadership qualities of school principals, as leadership studies carried out within the framework of western cultures have not been sufficienty questioned in eastern cultures (Bajunid, 1996; Cheng, 1993; Hallinger, 1995). Also, studies which are directed towards the implicit leadership perceptions of teachers are suggested. Another suggestion of the study is that the Ministry of Education takes into consideration the scientific research carried out and places emphasis to personal traits when choosing school principals. Moreover, the formation of conditions that will increase the external motivation of teachers is a concern for the Ministry of Education as well as for school principals due to its centralized structure. 


\section{References}

Adair, J. (2002). Effective strategic leadership. London: Macmillan Publishing.

Akbaba-Altun, S. (2003). İlköğretim okulu müdürlerinin dönüşümcü liderliğe verdikleri önem ve uygulama düzeyleri. Elementary Education Online, 2(1), 10-17. [Online] Available: http://ilkogretim-online.org.tr/vol2say1/v02s01b.pdf

Atakl1, A. (1996). İlkokul oğretmenliğinde kisisel niteliklerin ve işe gudulemenin onemi. Că̆das Ĕ̈itim Dergisi, 221, 21-28.

Bajunid, I. A. (1996). Preliminary explorations of indigenous perspectives of educational management: The evolving Malaysian experience. Journal of Educational Administration, 34(5), 50-73. http://dx.doi.org/10.1108/09578239610148278

Barlı, O., Bilgili, B., Çelikand, S., \& Bayrakçeken, S. (2005). İlköğretim okul öğretmenlerinin motivasyonları: farklılıkların ve sorunların araştırılması. Ataturk University Journal of Social Sciences, 5(1), 1-27.

Barth, R. (1986). Principal centered professional development. Theory Into Practice, 25(3), 156-160. http://dx.doi.org/10.1080/00405848609543218

Bass, B. M., \& Avolio, B. J. (1993). Transformational leadership: A response to critiques. M. M. Chemers \& R. Ayman (Eds.), Leadership theory and research: Perspectives and directions. (pp. 49-80). Academic Press: San Diego.

Bass, B.M. (1990). From transactinal to transformational leadership: Learning to share the vision. Organizational Dynamics, $\quad 18(3), \quad$ 19-31. http://dx.doi.org/10.1016/0090-2616(90)90061-S

Bingöl, D. (2006). Insan Kaynakları Yönetimi. Istanbul: Arıkan Basım Yayım Dağıtım.

Bottery, M. (2001). Globalisation and UK competition state: No room for transformational leardeship in education. School Leadership \& Management, 21 (2), 199-218. http://dx.doi.org/10.1080/13632430120054772

Brestrich, E. T. (1999). The Development of leadership in the understanding of management and administration and transformational leadership and an empirical study, Unpublished doctoral dissertation, Gazi University, Turkey.

Burns, M. G. (1978). Leadership. Newyork: Harper-Row Publiciations.

Bursalıglu, Z. (2002). Okul yönetiminde yeni yapı ve davranış. Ankara: Pegem Yayıncılık.

Caldwell, B.J., \& Spink, J.M. (1992). Leading the self-managing school. London: Palmer Press, Taylor and Francis, Inc.

Cheng, C. (1993). Profiles of organizational culture and effective schools. School Effectiveness and School Improvement, 4(2), 85-110. http://dx.doi.org/10.1080/0924345930040201 
Cheng, K. M. (1995). The neglected dimension: Cultural comparison in educational administration. In K. C. Wong \& K. M. Cheng (Eds.), Educational leadership and change: An intemntwnal perspective (pp. 87-104). Hong Kong: Hong Kong University Press.

Conger, J. A. (1999). Charismatic and transformational leadership in organizations: An insider's perspective on these developing streams of research. Leadership Quarterly, 10 (2), 145-170. http://dx.doi.org/10.1016/S1048-9843(99)00012-0

Conley,D. T., \& Goldman, P. (1994). Ten propositions for facilitative leadership. In J. Murphy \& K. S. Louis (Eds.), Reshaping the principalship: Insights from transformational reform efforts (pp. 237-262). Thousand Oaks, CA: Corwin Press.

Coutts, D. (1997). Measuring the degree of success in improving school climate in schools with new principals. Educational Research Information Clearinghouse. [Online] Available: http://www.eric.ed.gov/PDFS/ED407726.pdf

Covey, S.R. (1989). The 7 Habits of Highly Effective People. New York: Simon and Schuster Publishing.

Çelik, S., \& Eryılmaz, F. (2006). Transformational leadership levels of industrial vocational high school principals according to the teacher's perception. Journal of Polytechnic, 9(4), 211-224.

Dwyer, D. (1986). Understanding the principal's contribution to instruction. Peabody Journal of Education, 63(1), 3-18. http://dx.doi.org/10.1080/01619568509538499

Engle, E. A., \& Lord, R. G. (1997). Implicit theories, self-schemas, and leader - member exchange. Academy of Management Journal, 40, 988-1010. http://dx.doi.org/10.2307/256956

Epitropaki, O., \& Martin, R. (2004). Implicit Leadership Theories in Applied Settings: Factor Structure, Generalizability and Stability Over Time. Journal of Applied Psychology, 89, 293-310. http://dx.doi.org/10.1037/0021-9010.89.2.293

Ergin, C., \& Kozan, K. (2004). Çalişanların temel değerleri, dönüşümsel ve etkileşimsel liderlerin cekiciliği. Turkish Journal of Psychology, 19 (54), 37-51.

Eyal, O., \& Roth, G. (2011). Principal's leadership and teachers' motivation: Self determination theory analysis. Journal of Educational Administration, 49(3), 256 - 275.

Freeman, R. E., \& Stoner, J. (1992). Management. Englewood Cliffs: Prentice Hall.

Gallmeier, K. (1992). The effectiveness of principal leadership style on teacher motivation. [Online] Available: http://www.eric.ed.gov/PDFS/ED354591.pdf.

George, L., \& Sabhapaty, T. (2010). Work motivation of teachers: Relationship with transformational and transactional leadership behavior of college principals. Academic Leadership Journal, 8(2). [Online] Available: http://www.academicleadership.org/issue/Spring-2010 
Gibson, J. L, Ivancevich, J.M \& Donnelly, J.H. (1988). Organizations: Bahavior Structure Processes. Illinois: BPI-IRWIN.

Glad, B., \& Blanton, R. (1997). F.W. De Klerk And Nelson Mandela: A study in cooperative transformational leadership. Presidential Studies Quarterly, 27(3), 565-591.

Greenberg, J., \& Baron, R. A. (2000). Behaviour in organizations. New Jersey: Prentice Hall. Güçlü, N. (1996). Eğitim yönetiminde insan ilişkileri. Bilgi Çă̆ında Ĕ̆itim, 7, 16-20.

Hall, J., Johnson, S., Wysocki, A., \& Kepner, K. (2002). Transformational leadership: the transformation of managers and associates. [Online] Available: http://edis.ifas.ufl.edu

Hallinger, P. (1995). Changing norms of principal leadership in the United States. Journal of Educational Administration, 30(3), 35-48.

Hallinger, P., \& Leithwood, K. (1998). Unseen forces: The impact of social culture on school leadership. Peabody Journal of Education, 73(2), 126-151. http://dx.doi.org/10.1207/s15327930pje7302_6

Jacobs, K.D. (2007). Utilizing The William Allan Kritsonis Balanced Teeter-Totter Model as a means to cultivate a legacy of transformational leaders in schools: A national focus. National Forum of Educational Administration and Supervision Journal, 25(4), 1-6.

Kanungo, R. N., \& Mendonca. M. (1996). Cultural contingencies and leadership in developing countries. Research in the Sociology of Organizations, 14, 263 - 295.

Karkın, N. (2004). Kamu ve özel sektör yöneticilerinin liderlik davranışları: Bir literatür analizi denemesi. Türk İdare Dergisi, Sayı: 445,11-19.

Kenney, R. A., Blascovich, J., \& Shaver, P. R. (1994). Implicit leadership theories: Prototypes for new leaders. Basic and Applied Social Psychology, 15(4), 409-437. http://dx.doi.org/10.1207/s15324834basp1504_2

Kocabaş, I., \& Karaköse, T. (2005). Principals' behavior and attitudes' effect on the motivation of teachers. Journal of Turkish Educational Sciences, 3(1), 79-93.

Konrad, E. (2000). Implicit leadership theories in Eastern and Western Europe. Social Science Information, 39 (2),335-347. http://dx.doi.org/10.1177/053901800039002010

Krishnan, R. V. (2001). Value systems of transformational Leaders. Leadership and Organizational Development Journal, $\quad 22(3), \quad$ 126-131. http://dx.doi.org/10.1108/01437730110389274

Leithwood, K. (1992). The move toward transformational leadership. Educational Leadership, 49(5), 8-12.

Leithwood, K. (1995). Cognitive perspectives on leadership. Journal of School Leadership, 5, 115-135.

Leithwood, K., \& Jantzi, D. (1990). Transformational leadership: How principals can help 
reform school cultures. School effectiveness and school improvement, 1(4), 249-280. http://dx.doi.org/10.1080/0924345900010402

Leithwood, K., \& Jantzi, J. (1999). Transformational school leadership effects: a replication. School Effectiveness and School Improvement, 10(4), 451-474. http://dx.doi.org/10.1076/sesi.10.4.451.3495

Leithwood, K., Menzies, T. Jantzi, D., \& Leithwood, J. (1996). School restructuring, transformational leadership and the amelioration of teacher burnout. Anxiety, Stres And Coping, 9(3), 199-215.

Leithwood, K., Steinbach, R., \& Jantzi, D. (2002). School leadership and teachers' motivation to implement accountability policies. Educational Administration Quarterly, 38(1), 94-119.

Leong, L. Y. C., \& Fischer, R. (2010). Is transformational leadership universal? A meta-analytical investigation of multifactor leadership questionnaire means across cultures. Journal of Leadership \& Organizational Studies, 18(2) 164-174. http://jlo.sagepub.com/content/18/2/164

Lindner, J.R. (1998). Understanding employee motivation. Journal of Extension, 36 (3), 28-43.

Lord, R. G., Brown, D. J., \& Freiberg S.J. (1999). Understanding the dynamics of leadership: The role of follower self-concepts in the leader/follower relationship. Organizational Behavior Human Decision Processes, 78(3),167-203. http://dx.doi.org/10.1006/obhd.1999.2832

Lunenburg C., \& Ornstein, C. (2004). Educational administration: Concepts and practices. Belmont: Thomson Wadsworth Publishing.

Luthans, F. (1992). Organizational Behavior. USA: McGraw Hill

Maddock,R.C., \& Fulton, R.L. (1998). Motivation, emotions and leadership. Westport: Greenwood Publishing.

Marks, H. ve Printy, S. (2003). Principal leadership and school performance: An integration of transformational and instructional leadership. Educational Administration Quarterly, 39(3), 370-397. http://dx.doi.org/10.1177/0013161X03253412

Munn, L. N. (1968). Psikoloji insan intibakının esasları. (Çev. Nahid Tendar). İstanbul:Milli Eğitim Bakanlı̆̆

Nicholson, N. (2003). How to motivate your problem people. Harvard Business Review. [Online] Available: http://www.cs.unca.edu/ manns/HowToMotivateYourProblemPeople.pdf

Northouse, P. G. (1997). Leadership: Theory and practice. Thousand Oaks, CA: Sage Publications. 
Osterloh, M., Bruno, S., \& Frost, J. (2001). Managing motivation, organization and governance. Journal of Management and Governance, 5(3), 231-239. http://dx.doi.org/10.1023/A:1014084019816

Özdemir, S. (1998). Eğitimde örgütsel yenileşme. Ankara: Pegem Yayınları.

Öztürk. Z., \& Dündar, H. (2003). Organizational motivation and the factors which motivate the public workers. C. Ü. Iktisadi ve İdari Bilimler Dergisi, 4(2), 57-67.

Palmer, B., Walls, M., Burgress Z., \& Stough, C. (2001). Emotional intelligence and effective leadership. Leadership \& Organization Development Journal, 22(1),5-10. http://dx.doi.org/10.1108/01437730110380174

Pandey, S. K., Wright, B. E., \& Moynihan, D. P. (2008). Public service motivation and interorganizational citizenship behavior: Testing a preliminary model. International Public Management Journal, 11(1), 89-108. http://dx.doi.org/10.1080/10967490801887947

Park, S.M., \& Rainey, H. (2008). Leadership and public service motivation in US Federal Agencies. International Public Management Journal, 11(1), 109-142. http://dx.doi.org/10.1080/10967490801887954

Podsakoff, P.M., Mckanzie, S.B., Moorman, R.H., \& Fetter, R. (1990). Transformational leader behaviours and their effects on followers' trust in leader, satisfaction, and organizational citizenship behaviours. Leadership Quarterly, 1(2), 107-142. http://dx.doi.org/10.1016/1048-9843(90)90009-7

Robbins, S. (1996). Organizational Behavior. USA: PrenticeHall

Ruthankoon, R. ve Ogunlana, S. O. (2003). Testing Herzberg's two-factor theory in the Tai Construction Industry. Engineering, Construction and Architectual Management, 10(5), 333-341. http://dx.doi.org/10.1108/09699980310502946

Ryan, R. M., \& Deci, E. L. (2000). Self-determination theory and the facilitation of intrinsic motivation, social development, and well-being. American Psychologist, 55, 68-78. http://dx.doi.org/10.1037/0003-066X.55.1.68

Sagor, R. D. (1992). Three principals who make a difference. Educational Leadership, 49(5), 13-18.

Scott, P.G., \& Pandey, S. K. (2005). Red tape and public service motivation: Findings from a national survey of managers in state health and human service agencies. Review of Public Personnel Administration, 25(2), 155-180. http://dx.doi.org/10.1177/0734371X04271526

Selen, D. (2001). Liderlik mi yöneticilik mi? Geleneksel liderlik davranış tarzları ve bu konudaki yeni yaklaşımlara bir bakış. Atatürk Üniversitesi İktisadi ve İdari Bilimler Dergisi, 15(3), 247-278.

Simola, S. K., Barling, J. ve Turner, N. (2010). Transformational leadership and leader moral orientation: Contrasting an ethic of justice and an ethic of care. The Leadership Quarterly, 21, $179-188$. 
Snowden, E., \& Gorton, R. (2002). School leadership and administration. Boston:McGraw Hill

Sosik, J., Godshalk, J., \& Yammarino, F. (2004). Transformational leadership, learning goal orientation and expectations for career success in mentorprotege relationship: A multiple levels of analysis perspective. The Leadership Quarterly, 15, 241-261. http://dx.doi.org/10.1016/j.leaqua.2004.02.003

Spreitzer, G.M., Perttula, K.H., \& Xin, K. (2005). Traditionality matters: an examination of the effectiveness of transformational leadership in the United States and Taiwan. Journal of Organizational Behavior, 26, 205-227. http://dx.doi.org/10.1002/job.315

Stone, A.G., Russell, R.F., \& Patterson, K. (2003). Transformational versus servant leadership - a difference in leader focus. Servant Leadership Roundtable - October 2003.[Online] Available: http://www.regent.edu/acad/cls/2003servantleadershiproundtable/stone.pdf

Taş, A., Çelik, K., \& Tomul, E. (2007). Leadership styles of principals in elementary schools where the new program is implemented in Turkey. Pamukkale University Journal of Education Faculty, 22(2), 85-98.

Tichy, N.M., \& Ulrich, D.O. (2008). The leadership challenge - A call for the transformational leader. In Ott Parkes (Eds.). pp.210-239. Classical Readings of Organizational Behavior. Belmont: Thomson-Wadsworth.

Tosi, H. L., Mero, N. P., \& Rizzo, J. R. (2000). Managing organizational behavior. Malden, MA: Blackwell Publishing.

Triandis, H. C. (1995). Individualism and collectivism. Boulder, CO: Westview Press.

Ünal, S. (2000). İlköğretim okulu yöneticilerinin okullarında motivasyonu sağlama etkinlikleri. Pamukkale University Journal of Education Faculty, 7, 84-90.

Wegge, J. (2000). Participation in group goal setting: Some novel findings and a comprehensive model as a new ending to an old story. Applied Psychology: An International Review. 49, $498-516$.

$\mathrm{Wu}, \mathrm{X}$. (2003). Intrinsic motivation and young language learners: the impact of the classroom environment. System. 31, 501-517. http://dx.doi.org/10.1016/j.system.2003.04.001

Yamane, T. (2001). Temel Örnekleme Yöntemleri. (Çev. Alptekin Esin, Celal Aydın, M. Akif Bakır, Esen Gürbüzsel). İstanbul: Literatür Yayınları.

Yukl, G. (1999). An evaluation of conceptual weaknesses in transformational and charismatic Leadership theories. Leadership Quarterly, 10,(2), 285-305.

\section{Copyright Disclaimer}

Copyright reserved by the author(s).

This article is an open-access article distributed under the terms and conditions of the Creative Commons Attribution license (http://creativecommons.org/licenses/by/3.0/). 